\title{
Bank Characteristics Effect on Capital Structure: Evidence from PMG and CS-ARDL
}

\author{
Ahmet Erülgen ${ }^{1}$, Husam Rjoub ${ }^{1, *(\mathbb{D} \text { and Ahmet Adalıer }}{ }^{2}$ \\ 1 Department of Accounting and Finance, Faculty of Economics and Administrative Sciences, \\ Cyprus International University, Northern Cyprus via Mersin 10, 99258 Lefkosa, Turkey; aerulgen@ciu.edu.tr \\ 2 Department of Management Information Systems, School of Applied Sciences, Cyprus International \\ University, Northern Cyprus via Mersin 10, 99258 Nicosia, Turkey; aadalier@ciu.edu.tr \\ * Correspondence: hrjoub@ciu.edu.tr
}

Received: 28 October 2020; Accepted: 1 December 2020; Published: 4 December 2020

\begin{abstract}
The main aim of this paper was to investigate the impact of bank characteristics on capital structure empirically. The study employed a panel data analysis, Pooled Mean Group (PMG) and Cross-Sectionally Augmented Autoregressive Distributed Lag (CS-ARDL) estimators were utilized, for the period spans between the years 2008 and 2018. Both the borrowing (leverage) ratio and equity ratio used in the analysis cover short-term deposits and long-term deposits as a fundamental determinant variable on the capital structure. The main findings confirm that the deposit ratio has a positive relationship with the size of the bank. In other words, big banks use more foreign sources than small banks to use the tax shield advantage. At the same time, a percentage increase in bank size and liquidity ratio enhance the bank deposit rate by $0.0068 \%$ and $0.479 \%$, respectively, in the long-run, while a percentage change in interest income coverage will reduce the bank deposit rate by $0.004 \%$ in the long-run. Meanwhile, the significant causal relationship of growth rate with the bank deposit rate could not be established. In addition, the short-run coefficients of the variables reveal that size, interest coverage, and liquidity have a positive and significant causal relationship with bank deposit rate in the short-run. The findings of the study are in line with the results of capital structure theories, especially the hierarchy theory and balancing theory.
\end{abstract}

Keywords: optimum capital structure; financing; profitability; bank size; PMG; CS-ARDL

\section{Introduction}

A central bank is a financial institution given privileged control over the production and distribution of money and credit for a nation or a group of nations. The central bank is usually responsible for the formulation of monetary policy to achieve low and stable inflation and the regulation of member banks (Segal 2020). A central bank also acts as a lender of last resort in a financial crisis (Bindseil 2014). Most central banks also have supervisory and regulatory powers to ensure member institutions' stability to prevent bank runs and fraudulent behavior by member banks. Most of the central banks are not government agencies, but some of them are still nationalized. They are often touted as being independent of political interference. Still, limited control by the executive and legislative bodies exists. Central bank independence is usually guaranteed by legislation and the institutional framework governing the bank's relationship with elected officials (Blancheton 2016; Bodea and Higashijima 2017; Segal 2020).

Financial institutions, on the other hand, describe institutions that mediate fund flows. All financial institutions that mediate these fund flows between economic units (State, companies, and households) constitute the entire financial system. Central banks also pioneered with regulation and controls to ensure that this flow of funds operates smoothly and effectively (Kaya et al. 2013). Central Bank of North Cyprus is the only authority responsible for the oversight and supervision of 21 banks operating in the 
country and seven International Banking Units (North Cyprus Central Bank 2020). Deposits collected by these banks with their funds compose bank resources and are used in financing assets. The most basic bank costs are interest given to deposits because $80 \%$ of banks in North Cyprus are made up of deposits. The cost of capital shows how much of the capital held by banks cover the cost. It is one of the most basic indicators that show the patronage of the banks (North Cyprus Central Bank 2020). As a result of serial crisis and experiences learned, the role of the central banks has been shifted to another dimension. Central Banks (CBS) are an agent of economic diversification and employment creation. CBs are responsible for safeguarding macroeconomic stability in general and not just targeting price stability. At the same time, CBs have responsibilities to maintain low inflation and steady real growth of the economy as possible. Further, central banks are responsible for gathering stability of financial markets and those become more prominent during times of financial turmoil. However, many central banks are responsible for macro aspects of financial market stability, instead of individual banks and other financial institutions stability solely. Moreover, many CBs are helping the government in promoting economic development via bank credits to the priority sectors determined by the governments. Sometimes, central banks may need to finance excessive government deficits. Traditionally, central banks are safeguarding the financial system through acting as lender of last resort, operating or overseeing the payments systems, acting as an adviser to the government in matters involving legislation and regulation with respect to the financial sector, some but not all the central banks also act as supervisors of banks and other financial intermediaries. However, the structure of these roles, responsibilities given, and the range of other functions may vary between countries (Bis 2020).

Currently, there are many definitions of central banks that are all affected by the economic conditions. Within time, the definition of central banks has been shaped. Today, the aim of the Turkish Republic of Northern Cyprus TRNC Central Bank is to implement money-credit policies in accordance with development plans and annual programs, and to regulate and supervise the banking system. TRNC Central Bank is carrying out all necessary transactions for the regulation and supervision of the money and banking system of the country. TRNC Central Bank performs the following: takes into account the economic conditions to carry out the operations required to be done; supervising banks other money lending institutions; takes regulatory measures regarding the stabilization of the financial system, money, and foreign exchange markets; monitors the financial markets to establish payment settlement systems to make arrangements that will ensure the uninterrupted operation and control of the systems established and to be established; determines the methods and tools to be used, including electronic media for payments (North Cyprus Central Bank 2020).

North Cyprus Central Bank does not have its own currency to print money and supply it as a lender of last resort. In order to have a well-organized and effective financial system which is the assurance of the stability of the system, North Cyprus Central Bank is a sole authority to supervise the banks and other financial institutions in the country to make sure that the system works well. As an intermediary role of the banks from depositors to the creditors, it is essential to have a good selection of the source allocation and transfer channel between these parties. In addition, North Cyprus Central Bank has low interest rate rediscount credits which were used by the small and medium-sized enterprises during the financial crisis. For late liquidity, North Cyprus Central Bank has late liquidity window opportunities for the banks.

Capital structure is desired to be strong in banks because weak capital can cause a financial crisis by leaping into the financial crisis and then the real sector. For this reason, after the crises experienced by banks, "Bank of International Settlements" (BIS) was established in 1930 in Basel, Switzerland. BIS, which the central banks of developed countries established, formed the Banking Regulation and Supervision Committee, whose short name was Basel Committee in 1974 (Basel Committee on Banking Supervision BCBS). The Basel banking oversight committee was set up in the 12th month of 1974 under the decision of the central banks of G-10 countries under the International Payments Bank body, which was established in Basel, Switzerland, in 1930. The organization's founding members are; USA, Belgium, Germany, Canada, France, Italy, Netherlands, Japan, Spain, Switzerland, Sweden, England, 
and Luxembourg (Basel Committee on Banking Supervision BCBS). The objectives of this organization are: (i) To ensure the standard regulations and security of the international banking system, (ii) looking for new ways to audit banks, and (iii) it has goals, such as guiding national audits. The organization is not an official organization or organization in general. It is an organization in which the institutions of the countries are accepted. The recommendations and principles of this organization are generally accepted. These recommendations, which are accepted in most European countries, are broadening a shared vision globally (Basel Committee on Banking Supervision BCBS).

Basel Committee on Banking Supervision put forth Basel I in 1988, the Basel II in 2004, and Basel III in 2010, each of which is a set of international banking regulations. These regulations define the main objectives of bank capital, a measure of the degree of risk related to bank assets, the rules regarding minimum capital that must be held by a credit institution, for covering risks and analysis measures, supervision, and market discipline (Debajyoti et al. 2013; Mpundu et al. 2013). Due to its sensitive position, the banking sector is a sector that needs to be closely monitored, and its controls should be done in time and thoroughly. It should be determined that the banks' capital is evaluated via incorrect channels and that the instruments that make a profit for the bank are invested. The most significant cost, fixed and variable costs, should be evaluated and measured very well. The cost of the capital should be calculated well. The profitability should be maintained to reach the optimum capital structure, the bank characteristics determined by financial policies that banks follow in the efficient use of their assets, and the supply and management of their resources. The importance of bank characteristics in determining the optimum capital structure is undeniable. The borrowing (leverage) ratio used in the analysis is to cover both short-term deposits and long-term deposits as a fundamental determinant variable on the capital structure as well as equity ratio.

This study is significant in two ways. Firstly, its focus on the North Cyprus banking sector. The findings will shed some lights on the banks' capital structure in a small island economy. Secondly, the paper contributes to the empirical literature on the determinants of capital structure and island economy by extension. The remainder of the study is structured as follows: Section 2 consists of the review of related studies, Section 3 presents the data and empirical methodology. The empirical findings and discussions are presented in Section 4, and Section 5 rounds up the study with the conclusions.

\section{Literature Review}

Banks meet their financing needs either by using equity capital or by borrowing. Therefore, the capital structure explains the relationship between equity and debt. The capital structure that affects the capital cost of the bank represents the long-term debt of the investors and the return on equity (Allen et al. 2015). The capital structure has been an essential topic of discussion in the field of financial management for many years. In the study by Modigliani and Miller (1958), the question of whether the optimal combination of debt and equity maximizes the value of the company has been raised, and if so, the issue of which factors influence the optimal capital structure of the company is frequently discussed (Stiglitz 1969).

The financial policies followed by the management of the bank to increase the bank value determine the market value of the bank. However, not only the optimal use of bank assets is an adequate solution to maximize bank value, but it also affects bank value in financial policies followed in securing funds. Many business decisions are vital to the bank's financial structure (Mehran and Thakor 2011). A wrong conclusion about the capital structure can lead a bank to financial distress or even bankruptcy. Bank management tries to create the bank's capital structure in a way that maximizes the bank value (Elsas et al. 2010). Theoretical and empirical studies refer to the optimal capital structure, but financial managers do not have a precise method to achieve the optimum debt level (Gropp and Heider 2010). However, finance theory provides an understanding of the impact of the preferred financing mix on bank value. The capital structure theories have been developed to show how stock prices and capital costs are affected by the capital structure (Schepens 2016). The fundamental theories used in the finance literature explaining the optimal capital structure are examined in four sections. 
i. $\quad$ Trade-off Theory: Balancing theory is based on the balancing between the tax advantage provided by the use of foreign resources and the cost of financial distress. The works of Kraus and Litzenberger (1973), Scott (1976), and Kim (1978) have revealed the balancing theory. In these studies, it is suggested that banks should achieve an optimal ratio between foreign capital and equity. Accordingly, highly profitable companies should use more foreign resources to increase the tax advantage resulting from reducing the financial burden on debt from the tax base. However, it should be noted that excessive borrowing will increase the Bank's risk of bankruptcy (Bradley et al. 1984). These two different views on more or less borrowing policies of enterprises have led companies to seek optimal debt levels in order to maximize tax advantage and minimize bankruptcy risk (Schepens 2016).

ii. Agency Theory: The agency theory is based on disputes between shareholders and business executives and between shareholders and creditors. Studies on the power of attorney theory began to be carried out since the 1970s. In finance theory, the power of attorney relations have a significant effect on capital structure formation. The proxy relationships affecting the capital structure are divided into three groups. (i) Relations between shareholders and business executives representing them in business management. (ii) Relations between lenders and shareholders using their funds from the business. (iii) Relations between existing shareholders and potential shareholders. Existing shareholders have more information about the company than potential shareholders and keep this information confidential and in their own interests. If good returns are expected from the project, shareholders do not seek new shareholders for funding. Instead, by issuing low-interest debt, they keep a large part of the return on themselves (Berger and Patti 2006).

iii. Pecking Order Theory: Myers and Majluf (1984) have put together a new theory called financial hierarchy theory in the field of finance. According to this theory, investors who want to finance new investments apply to auto finance first, then to debt, and finally share certificates while forming the capital structure (Myers and Majluf 1984). Accordingly, banks do not have an optimal debt/equity ratio to be determined. The debt ratio of each bank cumulatively reflects the need for external financing. The debt ratio varies according to the level of resources created in the bank and investment expenditures. While profitable banks with limited investment opportunities have low debt ratios, banks with higher investment opportunities but with insufficient funds generated in banks have higher debt ratios (Myers and Majluf 1984). In determining debt ratios, the advantage of tax savings that the borrowing will provide with corporate tax, and the concern of financial crisis matters are of secondary importance. The hierarchy theory explains why the most profitable banks often use less debt. This is not because the target debt/equity ratios are low, but external funds are not needed. Less profitable banks borrow because they do not have sufficient internal funds for investment projects, and according to the hierarchy theory, debt is the primary source of external financing (Edmans and Mann 2019). Myers and Majluf (1984) hierarchy theory provides an alternative to traditional capital structure theory. Taggart (1986) examined the theory of hierarchy and revealed that hierarchy theory is more valid than optimal capital structure.

iv. Signaling Theory: The study conducted by Ross (1977) is based on the explanatory theory. As a result of information asymmetry, agencies with the best information provide the necessary information support to users with less knowledge. The increase in debt utilization is a favorable situation reported by companies to the market (Ross 1977). Highly profitable and growth-prone banks tend to borrow more than less profitable and non-growth banks. According to different theories of capital structure, there are factors affecting borrowing. Accordingly, the variables affecting borrowing are profitability, bank size, asset structure, changes in earnings, and growth opportunities. These variables affect borrowing both positively and negatively, according to the theories explained above regarding the capital structure (Ross 1977). 
Modigliani and Miller's joint studies (1958), which theoretically examined the effect of capital structure on bank value, put forward the theory of independence of capital structure, assuming that the capital structure determined had no effect on the bank value. Later, many researchers, including Modigliani and Miller, tried to measure the relationship between capital structure and bank value with less limited assumptions. Modigliani and Miller (1963) examined taxation and suggested that companies should use as much foreign capital as possible to achieve an optimal capital structure (Schepens 2016).

\section{Data and Model for Estimation}

\subsection{Data}

The data used in this paper are panel data that comprise nineteen (19) banks in North Cyprus and cover the period from 2006 Q1 to 2019 Q4. Currently, 21 banks are operating in the North Cyprus financial sector. The sample used in the study was 18 banks that were existed and operated between 2006 and 2019 which represents $98 \%$ of the overall banking sector total assets. In this study, bank-specific characteristics are considered to determine the capital structure. The bank capital structure was measured by two variables which are the deposit ratio (DR) that is calculated as the ratio of the bank's total short and long-term deposits to assets, and equity/assets. The independent variables used in the study were bank size (SIZE), liquidity ratio (LIQ), interest income coverage ratio (INTCOV), growth rate (GR), cost/income (COST_INC), and non-performing loan (NPL). The variables used in this paper are summarized in Table 1.

Table 1. Description of variables and sources.

\begin{tabular}{cccc}
\hline Symbol & Variables & Proxy & Source \\
\hline DR & Deposit Ratio & Dependent Variables & \\
EQUITY & Capital Adequacy & Total Deposits/Total Assets & North Cyprus Central Bank \\
SIZE & Ratio & Equity/Total Assets & North Cyprus Central Bank \\
INTCOV & Bank Size & Total Assets & North Cyprus Central Bank \\
LIQ & Liquidity & Phort-Term Liabilities/Ready Assets & North Cyprus Central Bank \\
GR & Growth Rate & (Asset 2 - Asset 1)/Asset 1 & North Cyprus Central Bank \\
COST_INC & Efficiency Ratio & Operating cost/Operating Income & North Cyprus Central Bank \\
NPL & Non-Performing Loans & Total (Gross) Non-Performing Loans & North Cyprus Central Bank \\
\hline
\end{tabular}

Descriptive statistics used in this paper are given in Table 2. As can be seen in Table 2, the variables have the same mean interval ensuring common features. Meanwhile, the variables' standard deviations are not high, inferring that the data are dispersed relatively close to the mean, and their dispersion is normal.

Table 2. Summary statistics.

\begin{tabular}{cccccc}
\hline Variable & Obs & Mean & Std. Dev. & Min & Max \\
\hline DR & 1064 & 0.7701 & 0.175 & 0.0339 & 1.189 \\
EQUITY & 1064 & 0.132 & 0.149 & -0.33 & 0.96 \\
SIZE & 1064 & 7.5533 & 1.0529 & 3.358 & 8.0375 \\
INTCOV & 1064 & 1.333 & 7.606 & 0.0595 & 119 \\
LIQ & 1064 & 0.265 & 0.1134 & 0.0565 & 0.915 \\
GR & 1064 & 0.3410 & 1.685 & -0.997 & 24.239 \\
COST_INC & 1064 & 1.34 & 3.28 & -2.27 & 39.60 \\
NPL & 1064 & 9.35 & 1.96 & 0.000 & 12.38 \\
\hline
\end{tabular}

Note: DR: deposit ratio, SIZE: bank size, LIQ: liquidity ratio, INTCOV: interest income coverage ratio, GR: growth rate, COST_INC: cost/income, EQUITY: equity/assets, NPL: non-performing loan. 


\subsection{Model for Estimation}

The panel ARDL model is considered to be among the most popular heterogeneous panel data estimators, but the model fails to address the potential cross-sectional dependence error (Chudik and Pesaran 2015; Wooldridge Jeffrey 2002). Therefore, in this study, the "Cross-Sectionally Augmented Autoregressive Distributed Lag (CS-ARDL)" (De V. Cavalcanti et al. 2015; Chudik and Pesaran 2015) in addition to the panel ARDL is employed. According to Chudik and Pesaran (2015), the "CS-ARDL model augments the ARDL model with the linear combination of the average cross-sectional of both the dependents variables and independent variables to capture the cross-sectional correlation in the error term". Chudik and Pesaran (2015) stressed further that in the estimation of the CS-ARDL, both "mean group (MG)" and "pooled mean group (PMG)" estimators were used. It should be noted that the time dimension $(\mathrm{T})$ is required to be large enough so that the model can be calculated for each cross-country unit. In addition, a sufficient number of lagged cross-section averages is required to be included so that validity of the estimators can be ensured.

It is required initially in the MG to estimate time series equations for each unit separately. The coefficients across units can then be calculated as the unweighted means of the calculated coefficients. It was suggested in the literature that the consistent estimates of the average of the parameters are being provided by MG when given a large time-series dimension (Pesaran 2015). It should be noted that no restrictions are imposed by MG on the cross-sectional parameters. Therefore, there could be different intercepts and coefficients; MG affords the maximum degree of heterogeneity. The disadvantage of such techniques is quite apparent. Meanwhile, Arnold et al. (2011) observed that MG estimators could be inefficient for a small cross-country dimension $(\mathrm{N})$. In addition, the estimator is sensitive to any unit outliers, which may influence the averages of the unit coefficients greatly (Arnold et al. 2011; Samargandi et al. 2015).

In light of these, the PMG estimator (Pesaran et al. 1999) is considered to be an alternative. Over the years, most empirical studies have widely applied PMG approach owing to it being an intermediate routine between the average and pooling methods of estimations (Arnold et al. 2011; De V. Cavalcanti et al. 2015; Odugbesan and Rjoub 2019, 2020). In the estimation of PMG, a two-step procedure is involved. First, the estimation of long-term slope coefficients jointly across units through a concentrated maximum likelihood procedure. Second, owing to the estimates of the long-term slope coefficients, intercepts, short-term coefficients, the speed of adjustment, and error variances are calculated via maximum likelihood on a unit-by-unit basis (Odugbesan and Rjoub 2019, 2020). According to Odugbesan and Rjoub (2019), the long-term slope coefficients in the PMG are essentially restricted to be homogenous across the cross-sections; however, it otherwise allows for heterogeneity. It was evident in some studies that the PMG approach provides consistent estimates of the mean of the short-term coefficients across units averaging individual unit coefficients owing to the lagged cross-units dimensions (Samargandi et al. 2015).

Meanwhile, some authors suggested that certain conditions are required for PMG application to ensure the validity of the estimates (De V. Cavalcanti et al. 2015; Samargandi et al. 2015). Among the condition is the existence of long-term relationships among the variables of interest, which could be checked through the negative and significance of the "error correction term" coefficient. Moreover, the model's dynamic specification should be largely augmented so that the independent variables can be treated as weakly exogenous. In addition, the resulting residuals from the ECM must be serially uncorrelated. However, the selection of the preferred estimator between MG and PMG approaches lies in the imposition of homogenous slopes for the estimated long-term parameters.

According to Arnold et al. (2011), "if the long-term coefficients are, in fact, not equal across countries, the MG estimates of the mean of long-term coefficients are consistent restrictions while the PMG estimates are inconsistent". However, "if the homogeneity restrictions are valid, estimators that impose cross-country constraints dominate the heterogeneous ones in terms of efficiency". However, "when the long-run coefficients are the same for individual units, both MG and PMG estimates are consistent, but only the latter is efficient" (Samargandi et al. 2015). Most studies 
considered PMG approach to be the best available compromise for consistency and efficiency most times (De V. Cavalcanti et al. 2015; Samargandi et al. 2015). Therefore, in this study, the empirical models employed are based on the "ARDL and CS-ARDL model specifications". The ARDL model's error correction form is utilized and specified as follows:

$$
\Delta y_{i t}=\omega_{i}+\alpha_{i}\left(y_{i, t-1}-\theta_{i}^{\prime} x_{i, t-1}\right)+\sum_{j=1}^{p-1} \varnothing_{i j} \Delta_{y i, t-j}+\sum_{j=0}^{q-1} \delta_{i j} \Delta x_{i, t-j}+\varepsilon_{i t}
$$

where, in model $1, y_{i t}$ is the deposit rate $(D R)$ for bank $i$ at time $t$. xit is a $6 \times 1$ vector of explanatory variables; bank size, liquidity ratio $(L I Q)$, interest income coverage ratio (INTCOV), and growth rate (GR). $\theta_{i}$ denotes "the long-term equilibrium relationship between $x_{i t}$ and $y_{i t}$ while $\phi_{i j}$ and $\delta_{i j}$ capture the short-term dynamics between variables". $\alpha_{i}$ represents "the speed of adjustment of the bank capital structure to the long-term equilibrium". Meantime, terms in brackets denote the cointegration relationship between $x_{i j}$ and $y_{i t}$. While, in model 2, only the deposit rate (DR) is substituted for equity/assets (EQUITY) as the dependent variable.

In a conventional panel ARDL approach, slope heterogeneity is accounted for together with different orders of integration in the variables. It can be used irrespective whether the independent variables are exogenous or not. Some problems were observed if the cross-section correlations in the errors are ignored (Phillips and Sul 2003). In other to avoid this problem, this study employed panel CS-ARDL, which according to Chudik et al. (2013) involves augmenting the right-hand side variable set with the cross-sectional averages of the regressors, the dependent variables, and a series of their lag values. These additional terms are meant to address the "cross-sectional correlation in the error term". The modified model is presented as follows:

$$
\begin{gathered}
\Delta y_{i t}=\mu_{i}+\alpha_{i}\left(y_{i, t-1}-\theta_{i}^{\prime} x_{i, t-1}+\alpha_{i}^{-1} n_{i} \bar{y}_{t}+\alpha_{i}^{-1} y_{i}^{\prime} \bar{x}_{t}\right)+\sum_{j=1}^{p-1} \varnothing_{i j} \Delta_{y i, t-j}+\sum_{j=0}^{q-1} \delta_{i j} \Delta x_{i, t-j} \\
+\sum_{j=0}^{p-1} v_{i k} \Delta \bar{y}_{t-j}+\sum_{j=0}^{q-1} y_{i k} \Delta \bar{x}_{t-j}+\varepsilon_{i t}
\end{gathered}
$$

where $\bar{y}_{t}$ and $\bar{x}_{t}$ represent the cross-section average of $y_{i t}$ and $x_{i t}$. In Equation (2), the short-term and long-term behavior of the cross-sectional correlation are distinguished. Furthermore, only the level parts of cross-sectional averages in included in the long-term equilibrium relationship in parentheses which is consistent with the suggestion of (Eberhardt and Presbitero 2015). The long-run coefficients associated with $y_{i t}$ and $x_{i t}$, that is $\theta_{i}$, and the rate of adjustment back to equilibrium, $\alpha_{i}$, are the main coefficients of interest. In order to ensure completeness, the short-run coefficients, $\phi_{i j}$, and $\delta_{i j}$ are also reported.

\section{Empirical Findings}

Consequent to the discussion above, the validity of panel ARDL approach is sacrosanct irrespective of whether the variables are $I(0)$ or $I(1)$, or a mixture of the two, hence the need to observe the stationarity properties of our variables. This study conducted an Im-Pesaran-Shin test (Im et al. 2003), and cross-sectionally augmented (Im-Pesaran-Shin) IPS test (Pesaran 2007). According to Im et al. (2003), IPS generally “allows for heterogenous an autoregressive parameters for each panel". This implies that under the null hypothesis for IPS, all panels have a unit root, and a rejection of the null hypothesis will indicate the stationarity of a non-zero fraction of panels. However, some studies stated that the presence of cross-sectional dependence poses a threat to the validity of the standard panel unit root test (De V. Cavalcanti et al. 2015; Eberhardt and Presbitero 2015), hence we applied the Cross-Sectional Augmented Im-Pesaran-Shin (CIPS) test (Pesaran 2007). This test (CIPS) allows for the heterogenous unit process through augmented the ADF regression for each unit with cross averages. The results for the two tests are presented in Table 3. As summarized and presented in Table 3, deposit rate (DR), bank size (size), liquidity ratio (LIQ), interest income coverage ratio (INTCOV), and growth rate (GR) are all $\mathrm{I}(0)$ series, which is an indication that the validity of our panel ARDL is guaranteed as none of the series is $I(2)$. 
Table 3. Im-Pesaran-Shin and Pesaran Cross-Sectional Augmented Im-Pesaran-Shin tests.

\begin{tabular}{cccc}
\hline Variable & IPS & CIPS & Integration Order \\
\hline Deposit rate & $-3.416^{* * *}$ & $-3.237^{*}$ & 0 \\
Equity & $-3.580^{* * *}$ & $-2.978^{* *}$ & 0 \\
Bank size & $-3.380^{* * *}$ & $-6.190^{* * *}$ & 0 \\
Liquidity ratio & $-4.204^{* * *}$ & $-3.722^{* *}$ & 0 \\
Interest income & $-4.203^{* * *}$ & $-3.882^{* *}$ & 0 \\
Growth rate & $-4.010^{* * *}$ & $-4.403^{* * *}$ & 0 \\
Cost_Inc & $-7.835^{* * *}$ & $-4.499^{* *}$ & 0 \\
LNPL & $-4.123^{* * *}$ & $-4.288^{* *}$ & 0 \\
\hline
\end{tabular}

Note: ${ }^{*}, * * * * *$ denote $10 \%, 5 \%$, and $1 \%$ significance level, respectively.

The results derived from the ECM specification in Equation (1) are presented in column 1 of Table 4. As earlier stated, MG is sensitive to unit outliers and could be inefficient is a small cross-units dimension. Thus, PMG estimator is considered to offer an attractive trade-off between consistency and efficiency. Owing to these, the long and short-run coefficients size, LIQ, INTCOV, GR, Const_Inc, and LNPL on deposit rate are derived from the PMG estimator in model 1 column 1, while the long and short-run coefficients size, LIQ, INTCOV, GR, Const_Inc, and LNPL on equity/assets are derived from the PMG estimator in model 2 column 3.

According to Loayza and Ranciere (2006), "the determination of the lag order of the ARDL model generally involves a trade-off between sufficient length and over-extension, owing to a few time-series dimension". Suffice to note that different authors have applied different approaches to selection of lag, and indeed, quite a number of studies have imposed a common lag structure for all units (Chudik et al. 2013), while some suggested that the selection of lag should be through information criterion (Arnold et al. 2011; De V. Cavalcanti et al. 2015). In view of this, this study selected the lag through BIC, subject to a maximum lag of 2 on each of the explanatory variables in the ARDL model, which resulted in the model incorporating a single period lag on each variable as shown in column 1 of Table 4.

Table 4. Estimate results of long and short-run effects.

\begin{tabular}{|c|c|c|c|c|}
\hline \multirow[b]{2}{*}{ No. of Lagged } & \multicolumn{2}{|c|}{ Model 1} & \multicolumn{2}{|l|}{ Model 2} \\
\hline & $\begin{array}{c}\text { PMG } \\
1\end{array}$ & $\begin{array}{c}\text { CS-ARDL } \\
2\end{array}$ & $\begin{array}{c}\text { PMG } \\
1\end{array}$ & $\begin{array}{c}\text { CS-ARDL } \\
2\end{array}$ \\
\hline \multicolumn{5}{|c|}{ Long-run Equation } \\
\hline$G R$ & $0.008(0.005)$ & $0.154^{* * *}(0.029)$ & 0.107 (0.002) & $0.103^{* * *}(0.021)$ \\
\hline InSize & $0.0068^{* * *}(0.00087)$ & $0.00289(0.0037)$ & $0.012^{* * *}(0.001)$ & $0.03(0.0037)$ \\
\hline INTCOV & $-0.004^{* * *}(0.00049)$ & $0.0302 *(0.0178)$ & $-0.004^{* * *}(0.0005)$ & $0.0302 *(0.018)$ \\
\hline LIQ & $0.479 * * *(0.060)$ & $2.255^{* *}(0.897)$ & $0.480^{* * *}(0.060)$ & $2.26^{* *}(0.897)$ \\
\hline Cost_inc & $0.312 * *(0.050)$ & $0.786^{* *}(0.365)$ & $0.011^{* * *}(0.003)$ & $0.102^{* * *}(0.10)$ \\
\hline$L N P L$ & $0.305(0.054)$ & $0.706^{* * *}(0.263)$ & $-0.207(0.001)$ & $0.023 *(0.010)$ \\
\hline \multicolumn{5}{|l|}{ Short-run Equation } \\
\hline$E C T$ & $-1.139^{* * *}(0.093)$ & $-0.944^{* * *}(0.183)$ & $-1.140^{* * *}(0.093)$ & $-0.930 * * *(0.183)$ \\
\hline$\Delta G R$ & $0.0103(0.012)$ & $0.327^{* * *}(0.0474)$ & $0.010(0.011)$ & $0.317^{* * *}(0.0460)$ \\
\hline$\Delta \operatorname{lnSize}$ & $0.0082^{* * *}(0.00069)$ & $-1.44 *(0.077)$ & $0.0082^{* * *}(0.00069)$ & $-1.40 *(0.080)$ \\
\hline$\triangle I N T C O V$ & $0.022^{* * *}(0.006)$ & $0.187^{* *}(0.0801)$ & $0.021^{* * *}(0.007)$ & $0.197^{* *}(0.0601)$ \\
\hline$\Delta L I Q$ & $0.314^{* * *}(0.044)$ & $1.329 * * *(0.405)$ & $0.314^{* * *}(0.044)$ & $1.129^{* * *}(0.405)$ \\
\hline Cost_inc & $0.103(0.013)$ & $0.501(0.365)$ & $0.011(0.003)$ & $0.201(0.10)$ \\
\hline$L \overline{P P L}$ & $0.205(0.054)$ & $0.306(0.263)$ & $-0.207(0.001)$ & $0.123(0.010)$ \\
\hline Constant & $0.688^{* * *}(0.0596)$ & $-1.944^{* * *}(1.83)$ & $0.688^{* * *}(0.0596)$ & $-1.844^{* * *}(1.83)$ \\
\hline Obs & 1008 & 1008 & 1008 & 1008 \\
\hline Pesaran CD & 14.621 & -0.465 & 8.521 & -0.701 \\
\hline$p$-Value & 0.000 & 0.721 & 0.000 & 0.321 \\
\hline
\end{tabular}

Note: ${ }^{*}, * *, * *$ denote $10 \%, 5 \%$, and $1 \%$ significance level, respectively. Values in parentheses are standard error. 
The result presented in column 1 of Table 4 shows that the ECT coefficient (-1.139) is statistically significant at the significance level of less than $1 \%$. This finding indicates that the systems return to equilibrium in case of a shock that causes a disequilibrium. In addition, it reveals a stable long-run cointegration among the variables. The upper part of the table, which shows the long-run coefficients of the variables, indicates that bank size (0.0068), liquidity ratio (0.479), and cost/income (0.312) have a positive and significant causal relationship with bank deposit rate interest income coverage ratio $(-0.004)$ was found to have a negative and significant relationship with bank deposit rate. This findings imply that a percentage increase in bank size, liquidity ratio and cost/income enhances the bank deposit rate by $0.0068 \%, 0.479 \%$, and $0.312 \%$, respectively, in the long-run, while a percentage change in interest income coverage will reduce the bank deposit rate $0.004 \%$ in the long-run. Meanwhile, the significant causal relationship of growth rate, cost, and non-performing loans with the bank deposit rate could not be established. In addition, the short-run coefficients of the variables, as shown in Table 4 reveal that size (0.0082), INTCOV (0.022), and LIQ (0.314) have a positive and significant causal relationship with bank deposit rate in the short-run.

Meanwhile, the validity of the PMG estimates in Column 1, which was contingent on the assumption that the errors are cross-sectionally independent, was examined through cross-section dependence $(C D)$ test. Specifically, the correlation coefficients between the time-series for each panel member were used. CD statistic is standard normally distributed under the $\mathrm{H}_{0}$ of cross-section independence; thus, the $\mathrm{H}_{0}$ is rejected the p-value is less than 0.05. This then implies that the PMG estimator failure to address the cross-units dependence renders the accuracy of PMG estimates questionable. In order to address this shortcoming, the CS-ARDL approach is employed, which involves the inclusion of additional lagged cross-sectional averages of both the dependent and independent variables in the estimation.

In reference to previous studies, some suggested a lag length of 2 (Chudik and Pesaran 2015; Eberhardt and Presbitero 2015), while Chudik and Pesaran (2015) stressed further that the lag length should not exceed 3. Therefore, 2 lags were selected for our estimation. As presented in column 2 of Table 4 under the CS-ARDL estimates, the $\mathrm{H}_{0}$ of cross-sectional dependence in the Pesaran CD test is not rejected, which is an indication that any cross-sectional dependence caused by common factors have been addressed when the regression is augmented with the lagged cross-sectional averages. Due to this, the estimates under the CS-ARDL model is preferred in this study.

From column 2 of Table 4, the estimated coefficient of ECT (-0.944) is negative and significance, which is consistent with previous studies that for a system to show the ability to return to equilibrium in the cause of a shock, the ECT coefficient must be negative and significant (Odugbesan and Rjoub 2019, 2020). The negative coefficient and significance of the ECT coefficient of our estimates is an indication that our system will return to equilibrium in the case of disequilibrium. In addition, the negative and significance of the ECT coefficient indicate a stable long-run cointegration among the variables in the estimation. The estimates result, as presented in Table 4, show GR, INTCOV, LIQ, Cost_inc, and LNPM to have positive and significant coefficients. The result shows that a percentage increase in growth rate will increase by about $0.154 \%$ in the bank deposit rate in the long-run, holding all other variables constant at $1 \%$ significance level. Similarly, a percentage changes in INTCOV, LIQ, Cost_in, and LNPL will increase the bank deposit rate holding other variables constant by $0.0302 \%, 2.255 \%, 0.786 \&$ and $0.706 \%$ with $10 \%, 5 \%, 5 \%$, and $1 \%$ confidence level, respectively, in the long-run. Differently from the PMG estimates for the short-run, the CS-ARDL shows all the variables to be significant except the Cost_in and LNPP who were found not to be significant. Though, bank size was found to have a negative and significant causal relationship with the bank deposit rate in the short-run. It is worthy to note that the use of CS-ARDL model, as presented in column 2 of Table 4 suggests that the problems of cross-section averages largely reduces residual cross-section dependence, as evident in the CD statistic $(-0.465)$ and $p$-value (0.721). This is an indication that estimates from the CS-ARDL estimation are valid and devoid of any shortcomings. 
The results from model 2 are somewhat similar to model 1 . The equity/assets were substituted as the dependent variable. The result as presented in Table column 3 for PMG estimation indicates that size, LIQ, and Cost_income, were found to have a positive and significant causal relationship with equity/assets. On the other hand, INTCOV was found to have a negative effect on equity/assets in the long-run. This findings imply that a percentage increase in bank size, liquidity ratio, and cost/income enhances the bank deposit rate by $0.012 \%, 0.480 \%$, and $0.011 \%$, respectively, in the long-run, while a percentage change in interest income coverage will reduce the bank deposit rate $0.004 \%$ in the long-run.

In the short-run estimates, similar results were observed only that INTCOV was found to have a positive causal effect on equity assets. Meanwhile, the ECT coefficient $(-1.140)$ was found to be significant, which is an indication that in the case of disequilibrium, the model will return to equilibrium with an adjustment speed of $114 \%$. In order to ensure that the result obtained from PMG estimation is devoid of bias of cross-sectional dependency issues, CS-ARDL was utilized for the estimation, and the results are presented in column 4 . The results show GR, INTCOV, LIQ, Cost-Inc, and LNPL to have a positive and significant causal relationship with bank equity assets in the long-run. However, in the short-run, GR, INTCOV, and LIQ were found to be positive and significant, while the size was found to be negative. Similar to PMG estimates, the ECT coefficient $(-0.930)$ was found to be significant, which is an indication of a possible return to equilibrium in case of any shock in the model. Finally, the Pesaran CD test result, as presented in Table 4 shows that the estimates for CS-ARDL have corrected the cross-dependency issue that was observed in the PMG estimation.

\section{Conclusions}

In this study, it is investigated how bank characteristics affect capital structure by using panel data analysis. In panel data analysis, PMG and CS-ARDL estimators were utilized. The borrowing (leverage) ratio used in the analysis covers both short-term deposits and long-term deposits as a fundamental determinant variable on the capital structure. According to the results of the analysis, the deposit ratio has a positive relationship with the size of the bank. In other words, big banks use more foreign sources than small banks to use the tax shield advantage. This result confirms the balancing theory. The liquidity ratio, which indicates the Bank's ability to meet the liabilities to be paid in the current period, was found to have a negative relationship with the borrowing (leverage) ratio. According to this result, banks with high liquidity power go to less borrowing. This is because the banks with high liquidity power have a high amount of current assets and create their own cash. As a result, banks use this cash generated for the continuation of their activities and credit expansion. This attitude of banks is consistent with the hierarchy theory. As a result of the analysis, there was a negative relationship between the ratio of interest income to interest expenses and the capital structure. Banks with higher interest income to cover interest expenses prefer to use less foreign resources. This ratio is also high, which means that the Bank's earnings are high. This negative relationship confirms the theory of hierarchy, which means that banks create their own funds due to their activities and use these funds in their own activities and investments.

A future study could investigate in more detail whether the optimum capital structure of the banks' characteristics in the sector will vary from country to country by the applied model in this study.

The results obtained show us that big banks tend to collect deposits as a foreign source instead of using their equity because of the tax shield advantage consistent with the balancing theory of the optimum capital structure theories. However, a high rate of concentration on deposits may have a risk of fragility at downturn periods of the economy. Big banks, in particular, collect deposits rather than borrowing as foreign resources. At the same time, banks with high liquidity power in the sector borrow less in order to continue their activities and to ensure credit expansion, which is their essential function. On the other side, a high amount of liquidity of the banking sector to compensate for their activities and giving additional credits have interest in earning opportunity cost. Excess liquidity means investing less to the interest-earning assets for the banks. To overcome this situation, banks need to increase the rate of the conversion of deposit to credit ratio. In addition to these, banks with high 
deposit rates are required to earn high interest income in order to meet these deposit interest. Since the net interest margin is high, large banks easily deal with this problem and use less foreign resources because they have high interest income and their earnings level is also high. Banks which are creating their own sources because of the high amount of earnings needs less foreign sources to finance their activities and they have a tendency to use their own funds to finance themselves. In addition to all these, banks with high growth potential use less foreign resources. Banks whose income levels have increased over the years have reached a point where they can provide the resources they need for themselves, so they do not need too much foreign financing. This can be the straight forward alternative for the regular periods, but the risk of the fragility of the financial sector or the overall economy in the future probably create a problem, especially for the small banks, because in recession periods, finding an advantageous financing opportunity will be limited and bear a high cost to the banks to borrow and finance their activities.

When all these findings are evaluated together, it is important for the stability of profitability and strong capital structure of the banks in Northern Cyprus to make more investments in their interest earning assets, such as loans, or invest more to their equity instead of keeping high liquidity. Thus, banks will be able to continue their operations more strongly in situations of economic or financial crises that are frequently exposed. Since the appropriate debt composition cannot be found easily in times of economic downturn, the fund needs of the banks should be identified in advance to be ready for the obstacles of the future borrowings. The trade-off between the level of using their own funds and the level of borrowings needs more attention to fix it.

Author Contributions: These authors contributed equally to this work. All authors have read and agreed to the published version of the manuscript.

Funding: This research received no external funding.

Conflicts of Interest: The authors declare no conflict of interest.

\section{References}

Allen, Franklin, Elena Carletti, and Robert Marquez. 2015. Deposits and bank capital structure. Journal of Financial Economics 118: 601-19. [CrossRef]

Arnold, Jens, Andrea Bassanini, and Stefano Scarpetta. 2011. Solow or Lucas? Testing speed of convergence on a panel of OECD countries. Research in Economics 65: 110-23. [CrossRef]

Basel Committee on Banking Supervision (BCBS). 2013. Basel III: The Liquidity Coverage Ratio and Liquidity Risk Monitoring Tools; Bank for International Settlements (BIS) Publications. Available online: http://www.bis.org/ publ/bcbs238.htm (accessed on 21 January 2020).

Basel Committee on Banking Supervision (BCBS). 2020. The Basel Committee-Overview. Available online: https://www.bis.org/bcbs (accessed on 16 January 2020).

Berger, Allen, and Emilia Bonaccorsi Di Patti. 2006. Capital structure and firm performance: A new approach to testing agency theory and an application to the banking industry. Journal of Banking and Finance 30: 1065-102. [CrossRef]

Bindseil, Ulrich. 2014. Monetary Policy Operations and the Financial System. Oxford: Oxford University Press, Available online: https:/www.oxfordscholarship.com/view/10.1093/acprof:oso/9780198716907.001.0001/ acprof-9780198716907 (accessed on 11 April 2020).

Bis. 2020. Roles and Objectives of Modern Central Banks. Available online: https://www.bis.org/publ/othp04_2.pdf (accessed on 10 May 2020).

Blancheton, Bertrand. 2016. Central bank independence in a historical perspective. Myth, lessons and a new model. Economic Modelling 52: 101-7. [CrossRef]

Bodea, Cristina, and Masaaki Higashijima. 2017. Central bank independence and fiscal policy: Can the central bank restrain deficit spending? British Journal of Political Science 47: 47-70. [CrossRef]

Bradley, Michael, Gregg A. Jarrell, and E. Han Kim. 1984. On the existence of an optimal capital structure: Theory and Evidence. The Journal of Finance 39: 857-78. [CrossRef] 
Chudik, Alexander, and M. Hashem Pesaran. 2015. Common correlated effects estimation of the terogeneous dynamic panel data models with weakly exogenous regressors. Journal of Econometrics 188: 393-420. [CrossRef]

Chudik, Alexander, Kamiar Mohaddes, and M. Hashem Pesaran. 2013. Debt, Inflation and Growth: Robust Estimation of Long-Run Effects in Dynamic Panel Data Models. CESifo Working Paper No 4508. Washington, DC: International Monetary Fund (IMF).

De V. Cavalcanti, Tiago V., Kamiar Mohaddes, and Mehdi Raissi. 2015. Commodity price volatility and the sources of growth. Journal of Applied Econometrics 6: 857-73. [CrossRef]

Debajyoti, Ghosh Roy, Bindya Kohli, and Swati Khatkale. 2013. Basel I to Basel II to Basel III. AIMA Journal of Management $\mathcal{E}$ Research 7: 474-97.

Eberhardt, Markus, and Andrea F. Presbitero. 2015. Public debt and growth: Heterogeneity and non-linearity. Journal of International Economics 97: 45-58. [CrossRef]

Edmans, Alex, and William Mann. 2019. Financing through asset sales. Management Science 65: 3043-60. [CrossRef]

Elsas, Ralf, Andreas Hackethal, and Markus Holzhäuser. 2010. The anatomy of bank diversification. Journal of Banking and Finance 34: 1274-87. [CrossRef]

Gropp, Reint, and Florian Heider. 2010. The determinants of bank capital structure. Review of Finance 14: 587-622. [CrossRef]

Im, Kyung So, Hashem Pesaran, and Yongcheol Shin. 2003. Testing for unit roots in heterogeneous panels. Journal of Econometrics 115: 53-74. [CrossRef]

Kaya, Abdülkadir, ünal Gülhan, and Güngör Bener. 2013. Türkiye Ekonomisinde Finans Sektörü ve Reel Sektör Etkileşimi. Akademik Araştırmalar ve Çalışmalar Dergisi (AKAD) 5: 2-15.

Kim, Han. 1978. A mean-variance theory of optimal capital structure and corporate debt capacity. The Journal of Finance 33: 45-63. [CrossRef]

Kraus, Alan, and Robert Litzenberger. 1973. A State-Preference Model of Optimal Financial Leverage. The Journal of Finance 28: 911-22. [CrossRef]

Loayza, Norman, and Romain Ranciere. 2006. Financial development, financial fragility, and growth. Journal of Money, Credit and Banking 38: 1051-76. [CrossRef]

Mehran, Hamid, and Anjan Thakor. 2011. Bank capital and value in the cross-section. Review of Financial Studies 24: 1019-67. [CrossRef]

Modigliani, Franco, and Merton Miller. 1958. The cost of capital, corporation finance and the Theory of Investment. American Economic Review 48: 261-97.

Modigliani, Franco, and Merton Miller. 1963. Corporate income taxes and the cost of capital: A correction. American Economic Review 53: 433-43.

Mpundu, Mubanga, M. A. Petersen, Janine Mukuddem-Petersen, and Frednard Gideon. 2013. Basel III and asset securitization. Discrete Dynamics in Nature and Society 439305: 1-19. [CrossRef]

Myers, Stewart, and Nicholas Majluf. 1984. Corporate financing and investment decisions when firms have information that investors do not have. Journal of Financial Economics 13: 187-221. [CrossRef]

North Cyprus Central Bank. 2020. Banks. Available online: http://kktcmerkezbankasi.org/tr/ (accessed on 27 April 2020).

Odugbesan, Jamiu Adetola, and Husam Rjoub. 2019. Relationship among HIV/AIDS Prevalence, Human Capital, Good Governance, and Sustainable Development: Empirical Evidence from Sub-Saharan Africa. Sustainability 11: 1348. [CrossRef]

Odugbesan, Jamiu Adetola, and Husam Rjoub. 2020. Evaluating HIV/Aids prevalence and sustainable development in sub-Saharan Africa: The role of health expenditure. African Health Sciences 20: 568-78. [CrossRef]

Pesaran, Hashem, Yongcheol Shin, and Ron Smith. 1999. Pooled mean group estimation of dynamic heterogeneous panels. Journal of the American Statistical Association 94: 621-34. [CrossRef]

Pesaran, Hashem. 2007. A simple panel unit root test in the presence of crosssection dependence. Journal of Applied Econometrics 22: 265-312. [CrossRef]

Pesaran, Hashem. 2015. Time Series and Panel Data Econometrics. Oxford: Oxford University Press.

Phillips, Peter CB, and Donggyu Sul. 2003. Dynamic panel estimation and homogeneity testing under cross section dependence. The Econometrics Journal 6: 217-59. [CrossRef] 
Ross, Stephen. 1977. Determination of financial structure: The incentive-signalling approach. The Bell Journal of Economics 8: 23-40. [CrossRef]

Samargandi, Nahla, Jan Fidrmuc, and Sugata Ghosh. 2015. Is the relationship between financial development and economic growth monotonic? Evidence from a sample of middle-income countries. World Development 68: 66-81. [CrossRef]

Schepens, Glenn. 2016. Taxes and bank capital structure. Journal of Financial Economics 120: 585-600. [CrossRef] Scott, James, Jr. 1976. A theory of optimal capital structure. The Bell Journal of Economics 7: 33-54. [CrossRef]

Segal, Troy. 2020. Central Bank. Investopedia. Available online: https:/www.investopedia.com/terms/c/ centralbank.asp (accessed on 21 April 2020).

Stiglitz, Joseph. 1969. A re-examination of the Modigliani-Miller theorem. The American Economic Review 59: 784-93. Taggart, Robert, Jr. 1986. Corporate financing: Too much debt? Financial Analysts Journal 42: 35-42. [CrossRef] Wooldridge Jeffrey. 2002. Econometric Analysis of Cross Section and Panel Data. Cambridge: MIT Press.

Publisher's Note: MDPI stays neutral with regard to jurisdictional claims in published maps and institutional affiliations.

(C) 2020 by the authors. Licensee MDPI, Basel, Switzerland. This article is an open access article distributed under the terms and conditions of the Creative Commons Attribution (CC BY) license (http://creativecommons.org/licenses/by/4.0/). 